\title{
Boron Dynamics in Agricultural Soils of the Cerrado: Study on Sources, Doses and Leaching
}

\author{
Jefferson Ferreira da Silva \\ Dept. of Agronomy, State Goiás University \\ Vila Dona Nilza - Setor Universitário, Ipameri - GO, 75780-000, Brazil \\ Tel: (+55) 64 98135-9426 E-mail: jeffersonferreira@grupoprodutec.com \\ Stephany Diolino Cunha \\ Dept. of Forest Sciences, Federal University of Lavras \\ Aquenta Sol, Lavras - MG, 37200-900, Brazil \\ Tel: (+55) $64992576367 \quad$ E-mail: cunhaflorestal@ outlook.com
}

\author{
Henyo Alves Rodrigues Dias \\ Dept. of Agronomy, State Goiás University
}

Vila Dona Nilza - Setor Universitário, Ipameri - GO, 75780-000, Brazil

Tel: (+55) $62994961550 \quad$ E-mail: henyorodriguesdias@gmail.com

\begin{abstract}
Matheus da Silva Araújo (Corresponding author)
Dept. of Soil Science, University of São Paulo
\end{abstract}

Av. Pádua Dias, 235 - Agronomia, Piracicaba - SP, 13418-900, Brazil

Tel: (+55) $64996097330 \quad$ E-mail: araujomatheus@usp.br

\section{Ednaldo Cândido Rocha}

Dept. of Agronomy, State Goiás University

Vila Dona Nilza - Setor Universitário, Ipameri - GO, 75780-000, Brazil Tel: (+55) 64981301557 E-mail: ednaldo.rocha@ueg.br 
Márcio da Silva Araújo

Dept. of Agronomy, State Goiás University

Vila Dona Nilza - Setor Universitário, Ipameri - GO, 75780-000, Brazil

Tel: (+55) 62998654358 E-mail: marcio.araujo@ueg.br

\author{
Adilson Pelá \\ Dept. of Agronomy, State Goiás University \\ Vila Dona Nilza - Setor Universitário, Ipameri - GO, 75780-000, Brazil \\ Tel: (+55) $62981123083 \quad$ E-mail: adilson.pela@ueg.br
}

Received: May 1, 2021 Accepted: May 19, 2021 Published: May 25, 2021

doi:10.5296/jas.v9i2.18581

URL: https://doi.org/10.5296/jas.v9i2.18581

\begin{abstract}
The objectives of this study were: to evaluate the leaching potential of B in a Latossolo Vermelho-Amarelo (Oxisol) as a function of sources and doses of this micronutrient; among the sources tested (boric acid, ulexite and the commercial source H2 Boro), to determine the one with the lowest leaching potential; to evaluate leaching losses at different doses in each soil layer evaluated; and to identify chemical and physical variables of soils that influence B leaching. For that, two experiments were conducted in a greenhouse. The first one tested B leaching in the soil, with the three sources under study and five doses of $\mathrm{B}(0 ; 12 ; 24 ; 36$; and $48 \mathrm{~kg} \mathrm{ha}^{-1}$ ), whereas the second experiment evaluated the influence of soil physical and chemical attributes on B leaching using soils randomly collected in 22 localities in southeastern Goiás, Brazil. Regardless of the dose applied, ulexite led to the lowest soluble B content in the profile of the analyzed soils and also in the leachate. Boric acid was the only source that showed a different behavior in relation to B content in the different soil layers and in the leachate. In the soil layer from 21 to $30 \mathrm{~cm}$, ulexite is the source with the lowest soluble B content. The behaviors of the more soluble sources, in this case boric acid and $\mathrm{H} 2$ Boro (H2 Agrosciences - Monoethanolamine borate), regardless of the dose, are very similar, being highly leachable in the profile of the Oxisol used. Soils with clayey texture and higher values of $\mathrm{H}+\mathrm{Al}$ and $\mathrm{CEC}$ were able to retain higher $\mathrm{B}$ contents in the upper portion their profiles (layers from 0 to $10 \mathrm{~cm}$ and 11 to $20 \mathrm{~cm}$ ), but soils with sandy texture and higher values of sum of bases showed greater B losses by leaching.
\end{abstract}

Keywords: oxisol, micronutrient, fertilization, nutrient loss 


\section{Introduction}

Knowledge on boron (B) dynamics in soil is important for both correcting a possible deficiency of this micronutrient and preventing toxicity cases, since the leaching and adsorption of this element are important components for defining a balanced fertilization, at the correct time and using the best source. It is known that the B available in soil comes from organic matter decomposition and also from the release of clay minerals (Fernandes, 2006; Goldberg and Glaubig, 1985). Absorption is dependent on the concentration in the soil solution and also on the reactions between the micronutrient and the adsorbents in the soil, such as iron and aluminum oxides, clay minerals, organic matter and calcium carbonate, which are directly linked to soil texture, $\mathrm{pH}$, liming and leaching, which are variables that influence soil B dynamics. Also, parent material and soil texture are pointed out as important influencers of the dynamics of this micronutrient in the soil (Leite et al., 2011).

B deficiency is very common, especially in sandy, organic matter-poor soils, because it can be leached to deeper soil layers, where the root system of plants does not reach, or due to periods of low moisture and under conditions of soil with exaggerated application of limestone, which hamper the absorption of nutrients by plants (Azevedo, 2001), resulting in decreases in yield and quality of the harvested product. The performance of B fertilization is directly related to the rapid leaching to deeper soil layers (Saltali et al., 2005; Communar and Keren, 2007; Favaretto et al., 2007; Oliveira Neto et al., 2009), mainly due to the high mobility of this nutrient in the soil solution. In addition, the high availability of the applied B, combined with the narrow range between deficiency and toxicity in plants, can easily lead to toxicity (Communar and Keren, 2007; Lima et al., 2007).

Another important factor to take into account is the choice of the most suitable source of B for soil application, since most B fertilizers have high solubility and, consequently, greater mobility in the soil and higher degree of leaching, especially in soils with sandy texture, which according to Mortvedt (1994) has caused an increase in the use of low-solubility sources, such as calcium and sodium borates (ulexite and colemanite) and also liquid fertilizers complexed with ethanolamine.

Available studies on the use of B in fertilization are still incipient and, in some cases, indicate divergent responses. For example, Trautmann et al. (2014) observed that the application of B doses up to $2 \mathrm{mg} \mathrm{dm}^{-3}$ in Latossolo Vermelho eutrófico (Oxisol) with sandy texture negatively interfered in the development of roots and without significant effect on the development of the shoots of soybean plants. In Thailand, Lordkaew et al. (2013), evaluating the effects of B using pots with complete nutrient solutions, in three varieties of rice (Oryza sativa L.) and in two planting seasons, found a high and positive correlation between grain weight $\left(\mathrm{g} \mathrm{plant}^{-1}\right)$ and grain set $(\%)$ and with the number of spikelets per plant. Therefore, in the face of controversies like this about the dynamics of B in different soil types, especially related to sources and doses, studies are needed to better clarify B dynamics in Cerrado soils as a function of sources and doses used.

This study was conceived in order to evaluate the following hypotheses: a) more soluble B sources must have higher potential for leaching and carrying the nutrient to deeper soil layers; 
(b) the amount of B leached must have an increasing linear relationship with the applied dose; c) soils with higher contents of clay and organic matter must leach less B than sandy soils. In order to test these hypotheses, the present study was conducted with the objectives of: evaluating the leaching potential of $\mathrm{B}$ in a Latossolo Vermelho-Amarelo (Oxisol) as a function of sources and doses (boric acid, ulexite and H2 Boro); determining the source with the lowest leaching potential; evaluating leaching losses at different doses in each soil layer evaluated; and identifying soil chemical and physical variables that influence B leaching.

\section{Method}

Two experiments were conducted in a greenhouse, in an experimental area of the Goiás State

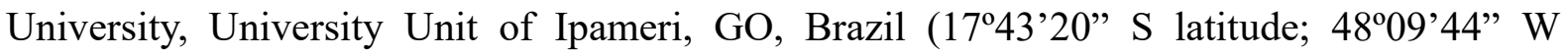
longitude; $764 \mathrm{~m}$ altitude). The climate of the region under study is classified as Aw (seasonal tropical) with average annual rainfall of $1,600 \mathrm{~mm}$, characterized by two well-defined seasons, a dry one in the winter, between May and September, and a rainy one in the summer, between October and April, with an average temperature of $23{ }^{\circ} \mathrm{C}$ (Alvares et al., 2013). The dimensions of the greenhouse used were $3.5 \mathrm{~m}$ ceiling height, $30.0 \mathrm{~m}$ length and $7.0 \mathrm{~m}$ width. Its sides were closed with $50 \%$ shade black net and its ceiling was covered with 150-micron transparent plastic.

In the first experiment, the design was completely randomized, arranged in a $3 \times 5$ factorial scheme with four replicates, and the first factor consisted of the sources boric acid, ulexite and $\mathrm{H} 2$ Boro ( $\mathrm{H} 2$ Agrosciences - Monoethanolamine borate), and the second factor was the doses of $\mathrm{B}\left(0 ; 12 ; 24 ; 36\right.$; and $\left.48 \mathrm{~kg} \mathrm{ha}^{-1}\right)$. Because there are no plants in the pots, we chose to use high doses in order to assess the potential for losses from the sources studied.

The experimental unit was composed of a PVC pipe with diameter of $10 \mathrm{~cm}$ and height of 33 $\mathrm{cm}$ (Figure 1), which was made using two PVC pipe rings with $10 \mathrm{~cm}$ height each at the base and one $13 \mathrm{~cm}$ high ring at the top. 


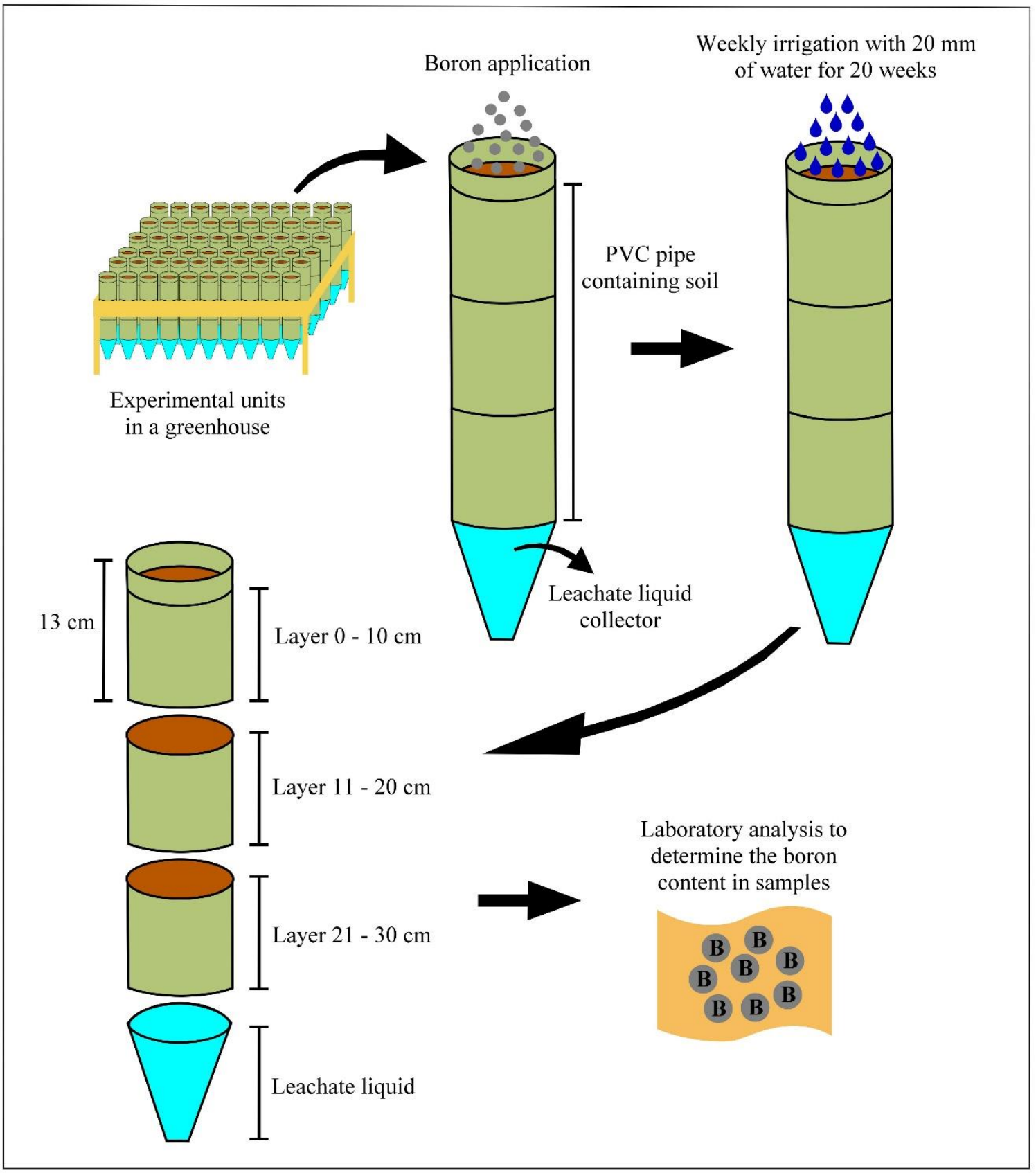

Figure 1. Schematic drawings illustrating the stages of experiments conducted in greenhouse and laboratory to evaluate B leaching. Ipameri - GO, Brazil, 2019

These rings were fixed to each other with adhesive tape and filled to a height of $30 \mathrm{~cm}$ with medium-textured Latossolo Vermelho-Amarelo (Oxisol) (Embrapa, 2018) collected in the surface layer $(0$ to $40 \mathrm{~cm})$, whose chemical analysis is presented in Table 1 . 


\section{Macrothink}

Table 1. Physical-chemical characteristics of the Latossolo Vermelho-Amarelo (Oxisol), before the experiment, in Ipameri - GO, Brazil, 2019

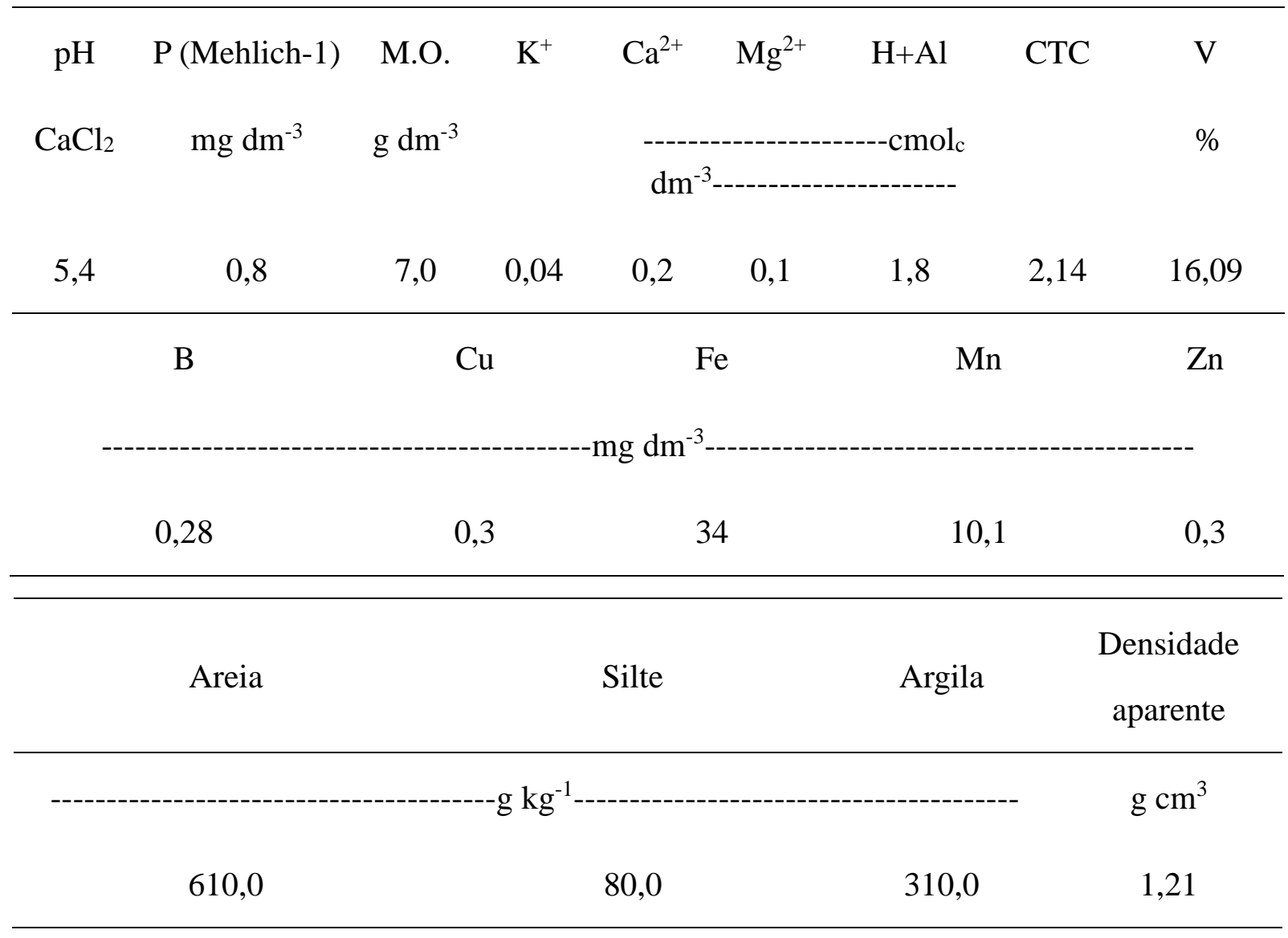

Extractants: $\mathrm{P}$ and $\mathrm{K}-$ Mehlich-1; $\mathrm{Ca}^{2+}, \mathrm{Mg}^{2+}$ and $\mathrm{Al}^{3+}-1 \mathrm{~mol} / \mathrm{L} \mathrm{KCl} ; \mathrm{H}+\mathrm{Al}-0.5 \mathrm{~mol} / \mathrm{L}$ calcium acetate at $\mathrm{pH} 7.0 ; \mathrm{B}$ - saturation extract in water; $\mathrm{Cu}, \mathrm{Fe} ; \mathrm{Mn}$ and $\mathrm{Mn}-\mathrm{DTPA} / \mathrm{CaCl}_{2}$ $(\mathrm{CAT}) . \mathrm{OM}=$ soil organic matter. $\mathrm{V}=$ base saturation. $\mathrm{H}+\mathrm{Al}=$ potential acidity. $\mathrm{CEC}=$ cation exchange capacity.

Percolated irrigation water collectors were installed at the bottom of the pipe of each soil column and B was applied to the surface of each soil column. When the treatments were applied, the moisture content was close to the maximum water retention capacity, which was defined considering a soil sample dried in an oven at temperature of $110{ }^{\circ} \mathrm{C}$ until reaching constant weight and subsequently soaked up to saturation. After the water stopped draining, the sampled was weighed and the difference between weights was calculated.

In the second experiment, the design was completely randomized with 22 treatments (soils from different localities) and four replicates. The experimental unit was the same adopted in the previous experiment. These containers were filled with soils randomly collected in 22 different locations, until obtaining a soil column of $30 \mathrm{~cm}$, also placing a collector for percolated irrigation water at the bottom of each soil column (Figure 1). Four PVC columns were prepared for each soil studied. Samples of these soils were taken and analyzed for physical and chemical characterization before the experiment. Subsequently, B doses were applied on the upper part of each column according to previous soil analyses, in order to raise 
the contents of this element to $2 \mathrm{mg} \mathrm{dm}-3$. For this experiment, boric acid was used as a source of B.

In both experiments, the soil in the PVC pipes was irrigated weekly with a $20 \mathrm{~mm}$ water depth until totaling $400 \mathrm{~mm}$ of accumulated water, i.e., volume that is usually accumulated after the beginning of the summer season in the region of Ipameri-GO, corresponding to approximately the precipitation that occurs in 20 weeks in this period (duration of the experiment). The soil solution percolated in the experimental units was collected along the entire experiment and subjected to chemical analysis in order to determine the amount of B leached throughout the period.

After all irrigations ended, the soil samples of each layer $(0$ to $10 \mathrm{~cm}, 11$ to $20 \mathrm{~cm}$ and 21 to $30 \mathrm{~cm}$ ) were removed from the pipes and were subjected to chemical analysis to determine the amounts of B in each soil layer, showing the mobility of the micronutrient along the soil profile according to the different sources, doses and chemical and physical attributes of the soils.

\subsection{Laboratory Analyses}

B content analyses were conducted by solubilization with hot barium chloride solution (Silva, 2009). For this, samples with $10 \mathrm{~cm}^{3}$ of soil, $0.5 \mathrm{~cm}^{3}$ of activated charcoal and $20 \mathrm{~mL}$ of barium chloride were placed in plastic bags and pressed with a sealer. Soon after a hole was made using a metal paper clip and the plastic bags were hung on polyethylene shelf and kept in a microwave for 4 minutes at maximum power $(750 \mathrm{~W})$ and for 5 minutes at medium power $(490 \mathrm{~W})$. After the material reached room temperature, filtration was performed to obtain an extract. B content was determined by spectrometry using the Azomethine-H method, with readings at the wavelength of $420 \mathrm{~nm}$. The methodology used for analyzing the B present in the leached material was the same as the methodology adopted for soil extracts (Silva, 2009).

\subsection{Data Statistical Analysis}

Statistical analyses were performed using B content data (in $\mathrm{mg} \mathrm{dm}-3$ ) obtained in both experiments for the three soil layers and for the leachate. For the data of the first experiment, the normality of residuals and homogeneity of variances were tested and, in case of non-compliance with these methodological assumptions [which occurred mainly in the comparison between B sources at each dose (Figure 3)], it was opted to use nonparametric statistical techniques. Thus, the Kruskal-Wallis nonparametric test was applied to compare the factors soil layers/leachate at each B source and B sources at each dose and in each layer, and multiple comparisons of the treatments were performed by the median test. Additionally, simple linear regression analysis was performed for the B doses factor. The data of the second experiment was subjected to principal component analysis (PCA), by correlation, using Euclidean distances as measures of dissimilarity between the samples.

Statistical analyses were conducted in R software version 3.5.1 (R Core Team, 2018), using the agricolae package (Mendiburu, 2017) for statistical calculations and the ggplot2 (Wickham, 2016) and factoextra (Kassambara and Mundt, 2017) packages for the graphical 
representation of the results.

\section{Results}

A significant difference was observed $(\mathrm{H}=12.43 ; \mathrm{p}=0.006)$ in the soluble $\mathrm{B}$ content in the soil layers and in the leachate for the boric acid source, and the B content retained in the soil layer from 0 to $10 \mathrm{~cm}$ was higher than the B content leached (Figure 2). On the other hand, for the sources $\mathrm{H} 2$ Boro and ulexite, there was no significant difference between the soil layers analyzed and the leachate $(\mathrm{P}>0.05)$.
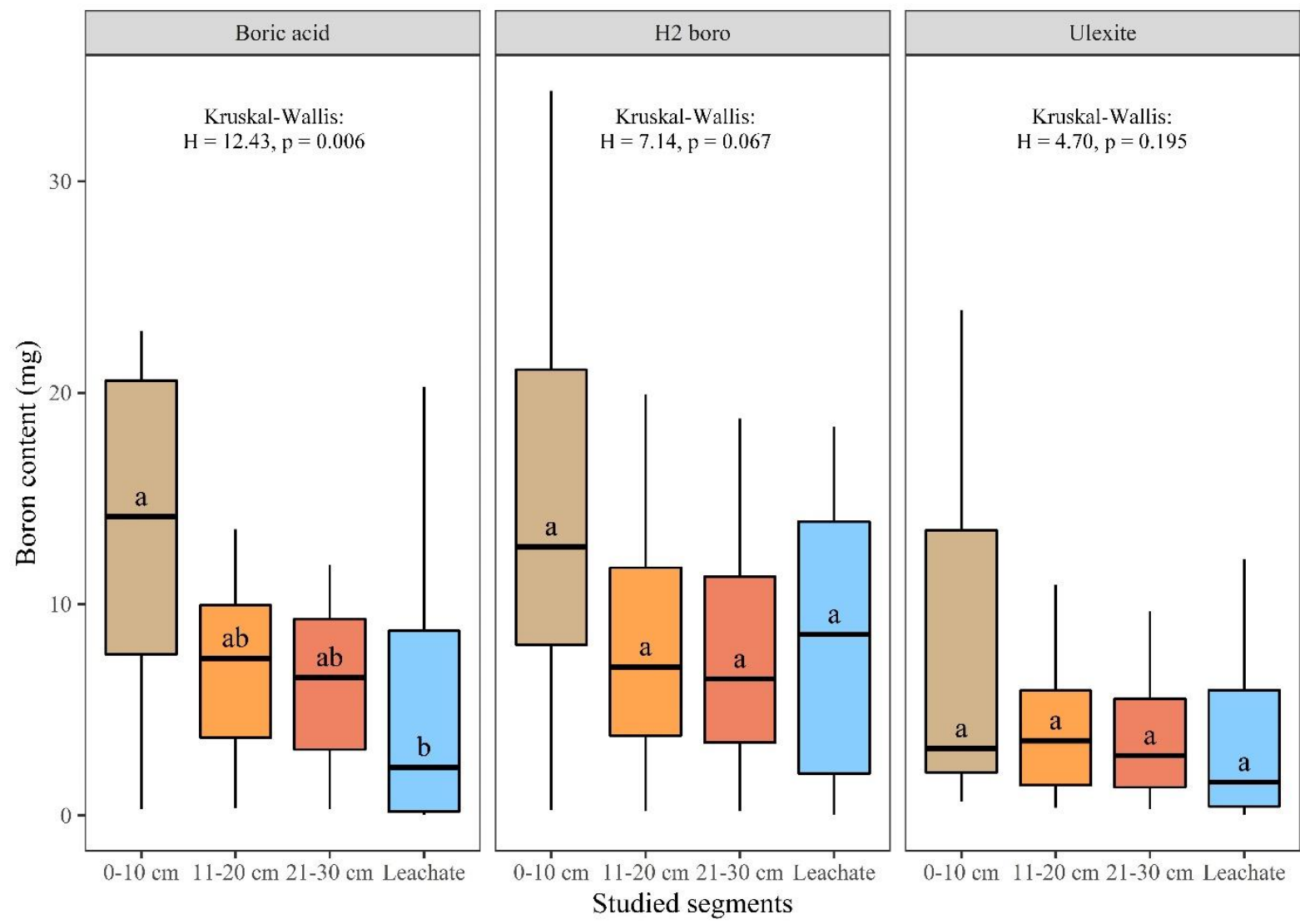

Figure 2. Box-Plot presenting the results of Kruskal-Wallis analysis and median test to compare the studied segments (soil layers and leachate) for each B source. For each source used, medians of B content followed by the same letter did not differ $(\mathrm{p}>0.05)$

Regardless of the B dose applied $\left(12,24,36\right.$ and $48 \mathrm{~kg}$ of B ha- $\left.{ }^{-1}\right)$, when the data are evaluated without being separated by segments (soil layers and leachate), ulexite led to the lowest soluble B content compared to the other sources ( $\mathrm{p}<0.05)$, and boric acid and H2 Boro were similar $(\mathrm{p}>0.05)$ at all doses applied (Figure 3). 


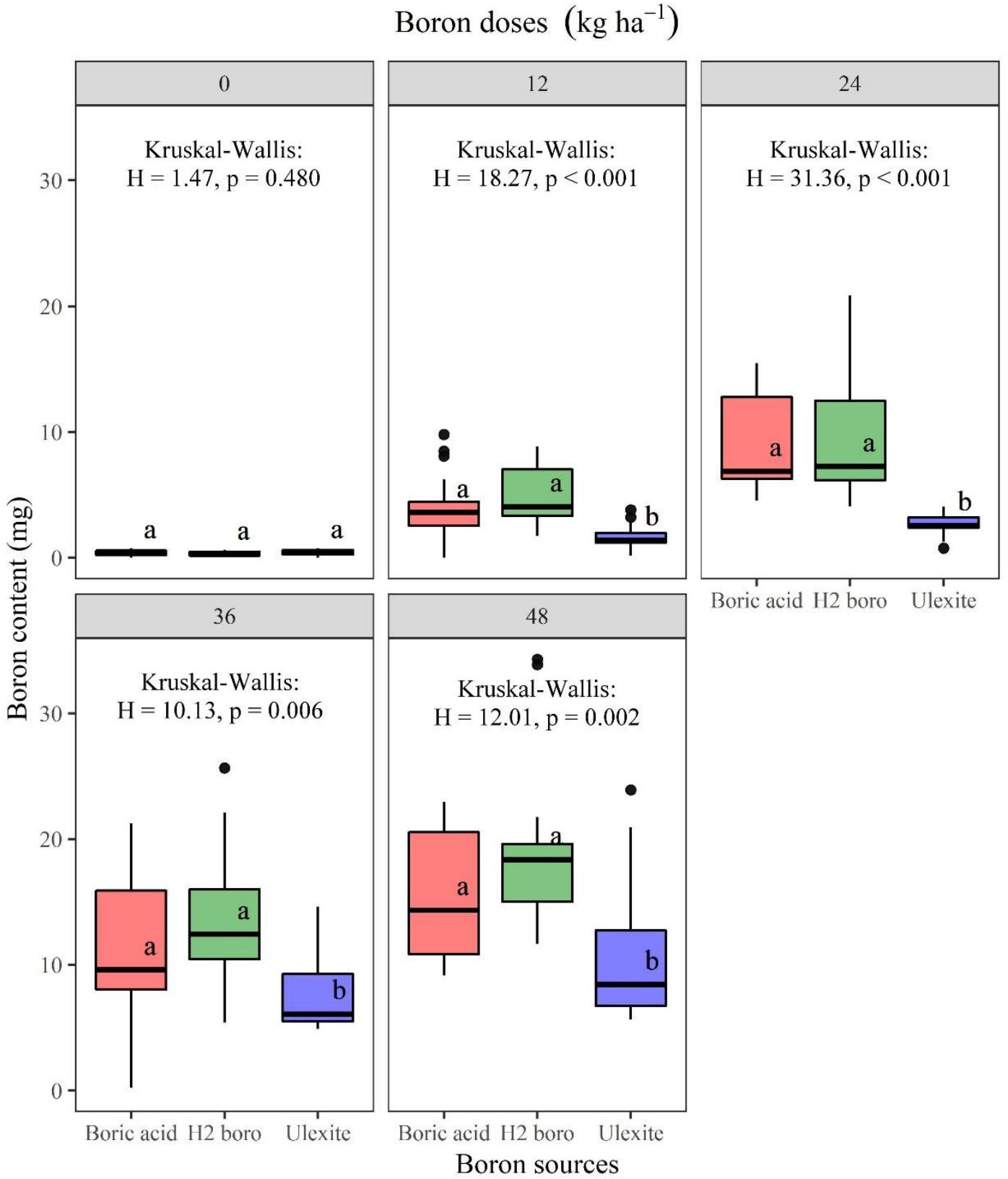

Figure 3. Box-Plot presenting the results of Kruskal-Wallis analysis and median test to compare B sources at each B dose applied $\left(0,12,24,36\right.$ and $\left.48 \mathrm{~kg} \mathrm{ha}^{-1}\right)$. For each dose used, medians of $\mathrm{B}$ content followed by the same letter did not differ $(\mathrm{p}>0.05)$

The ulexite source maintained the lowest soluble B content in the deepest soil layer (from 21 to $30 \mathrm{~cm}$ ). However, in the other segments studied (soil layers from 0 to $10 \mathrm{~cm}$ and 11 to 20 $\mathrm{cm}$ and in the leachate), the three sources resulted in statistically similar B contents ( $p>0.05$ ) (Figure 4). 


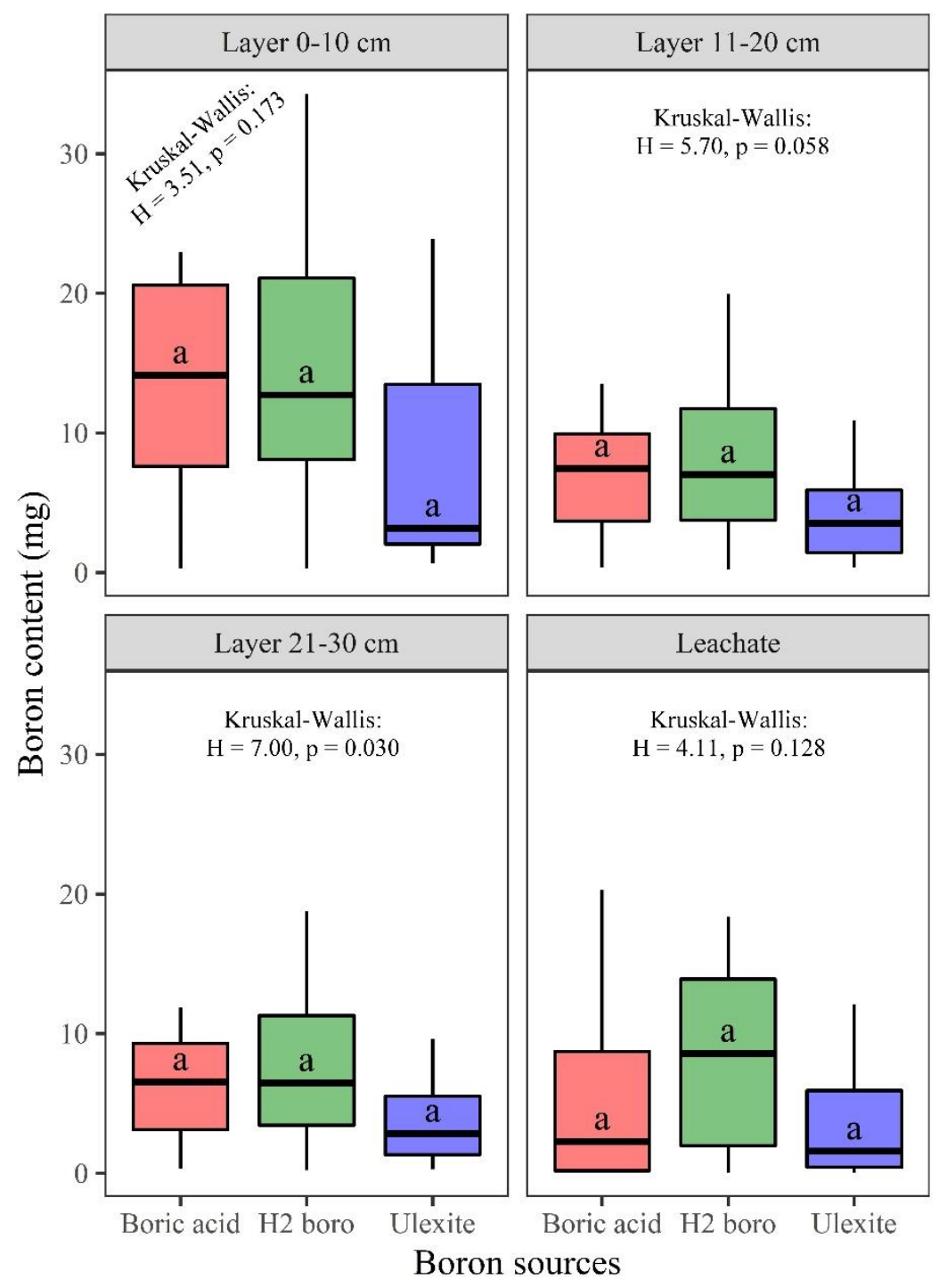

Figure 4. Box-Plot presenting the results of Kruskal-Wallis analysis and median test to compare B sources in each evaluated segment (soil layers and leachate). For each segment studied, medians of B content followed by the same letter did not differ $(p>0.05)$

There was increasing linear fit for the soluble B content in all segments evaluated (soil layers and leachate) as the applied B doses increased (Figure 5). The H2 Boro source led to the highest $\mathrm{B}$ contents in all three soil layers and in the leachate up to the dose of $36 \mathrm{~kg} \mathrm{ha}^{-1}$, followed by the sources boric acid and ulexite.

In relation to the highest $\mathrm{B}$ dose used $\left(48 \mathrm{~kg} \mathrm{ha}^{-1}\right)$ : in the soil layer from 0 to $10 \mathrm{~cm}$, ulexite resulted in a $\mathrm{B}$ content $23.6 \%$ lower than that caused by $\mathrm{H} 2$ Boro and $5.6 \%$ lower than that caused by boric acid; in the soil layer from 11 to $20 \mathrm{~cm}$, the B content of the ulexite source was $49.2 \%$ lower than that of the $\mathrm{H} 2$ Boro and $28.8 \%$ lower than that of boric acid; in the soil layer from 21 to $30 \mathrm{~cm}$, ulexite resulted in a B content $55.1 \%$ lower than that of $\mathrm{H} 2$ Boro and $25.4 \%$ lower than that of boric acid; and in the leachate, ulexite led to leached B content $51.8 \%$ lower than that of $\mathrm{H} 2$ Boro and $55.4 \%$ lower than that of boric acid (Figure 5). 

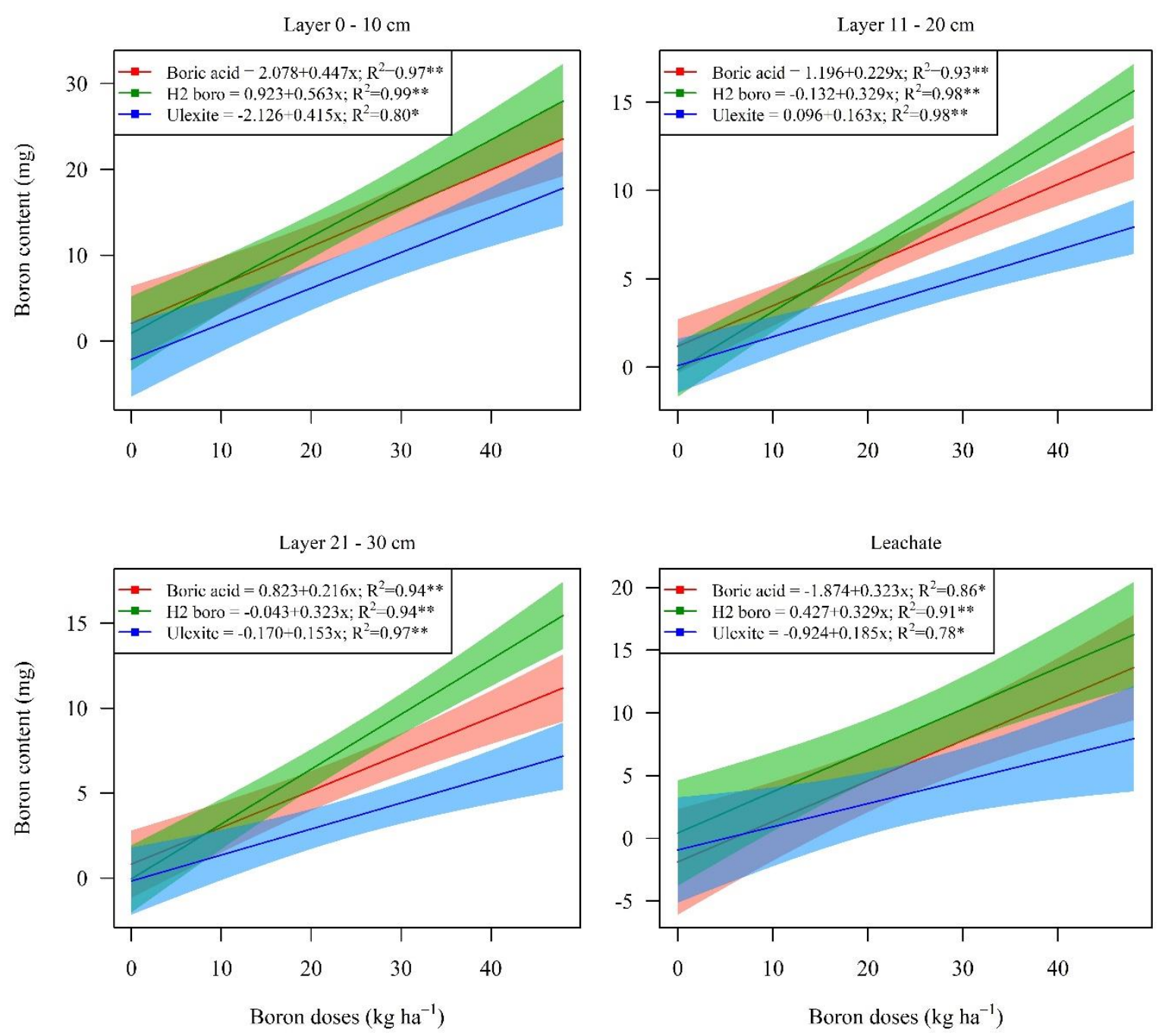

Figure 5. Result of regression analysis for B doses as a function of B sources, soil layers from 0 to $10 \mathrm{~cm}, 11$ to $20 \mathrm{~cm}, 21$ to $30 \mathrm{~cm}$ and leachate. Vertical bars indicate the standard errors of the means. $*$ and $* *=$ significant at 5 and $1 \%$ probability levels, respectively

Soils with the highest contents of organic matter and clay and with the highest values of $\mathrm{H}+\mathrm{Al}$ and $\mathrm{CEC}$ were the ones that maintained the highest $\mathrm{B}$ contents in the layers from 0 to $10 \mathrm{~cm}$ and from 11 to $20 \mathrm{~cm}$ (Figure 6, A and B). On the other hand, both in the layer from 21 to $30 \mathrm{~cm}$ and in the leachate, the soils with the highest percentages of sand and higher values of sum of bases had higher B contents (Figure 6, C and D), indicating greater leaching of this micronutrient. 

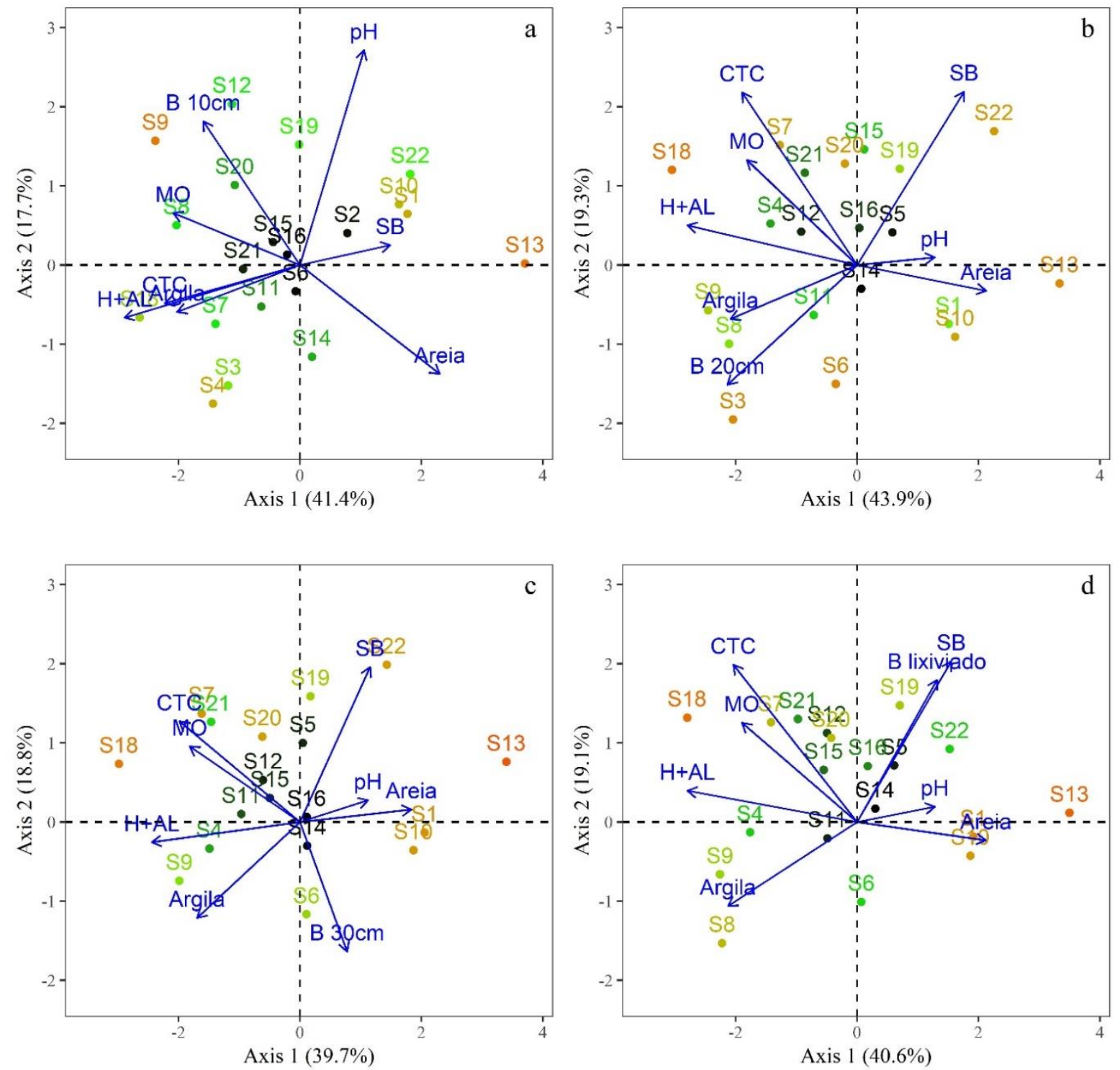

Figure 6. Result of principal component analysis for the physicochemical variables [organic matter (OM), cation exchange capacity (CEC), sum of bases (SB), potential acidity $(\mathrm{H}+\mathrm{Al})$, $\mathrm{pH}$, clay and sand] of soils from 22 different localities (S1 to S22) in southeastern Goiás and B contents in four segments of these soils [layers of $0-10 \mathrm{~cm}(B 10 \mathrm{~cm})(\mathrm{a}), 11-20 \mathrm{~cm}$ (B $20 \mathrm{~cm})(\mathrm{b}), 21-30 \mathrm{~cm}(\mathrm{~B} 30 \mathrm{~cm})(\mathrm{c})$ and leachate $(\mathrm{d})$

\section{Discussion}

B retention in the soil surface is significantly influenced by the source of this micronutrient. In regard to the soil layers, the boric acid source showed a significant difference only between the soil layer from 0 to $10 \mathrm{~cm}$ and the leachate, because the average B content in the first soil layer was about six times higher than the amount present in the leached material. This result corroborates those reported by Oliveira Neto et al. (2009), who verified linear increase in B leaching as a function of doses, at all soil depths, as observed in our study. 
Ulexite, for all doses tested, was the source that led to the lowest B content in the soil layers, because it is poorly soluble in the soil, a result explained by Trautmann (2014), who observed that $\mathrm{B}$ sources differ at the dose of $1 \mathrm{mg} \mathrm{dm}^{-3}$ with the application of colemanite, a less soluble and less leachable source, with higher values of root mass and volume in soybean crop.

In the soil layer from 21 to $30 \mathrm{~cm}$, ulexite differed statistically from the other sources because the B content found was much lower than those caused by the other sources (boric acid and H2 Boro) regardless of the tested layer. These results are explained by Byers et al. (2001), who state that boric acid is the B source of greater solubility in water and low reactivity in the soil, having a high initial availability and greater susceptibility to leaching. On the other hand, colemanite has low solubility, like ulexite, and slow release, being less subject to leaching (Murphy and Walsh, 1972).

With the increase in the applied doses, the B contents in the different soil layers and in the leachate increased linearly, regardless of the source. Azevedo et al. (2001) stated that B adsorption occurs up to a certain critical point, from which the adsorption becomes low. Therefore, fertilization with B from this level will only result in greater loss of the nutrient by leaching. For this reason, even when high B doses are used in Cerrado soils, it is not common to observe symptoms of toxicity in crops, because when B is added to the soil, depending on the source, much of this element can be lost by leaching.

It can be affirmed that up to the $\mathrm{B}$ dose of $12 \mathrm{~kg} \mathrm{ha}^{-1}$ the more soluble sources such as boric acid and $\mathrm{H} 2$ Boro can be used in short-term fertilization because they are readily available, but caution should be taken in choosing the applied dose, as this micronutrient has a narrow range between ideal and toxicity. In this context, Foloni et al. (2010) evaluated four B doses borax $\left(0 ; 1 ; 2\right.$ and $\left.3 \mathrm{~kg} \mathrm{ha}^{-1}\right)$ applied to the soil and four $\mathrm{B}$ doses - boric acid $(0 ; 0.5 ; 1$ and 2 $\mathrm{kg} \mathrm{ha}^{-1}$ in spray volume) applied on the leaves of the sunflower crop and found increase in the size of sunflower grains as B fertilization increased, but on the other hand, when B doses of 2 and $3 \mathrm{~kg}$ ha- 1 were added at sowing, high doses of B sprayed on the leaves compromised the formation of grains due to toxicity of this micronutrient.

$\mathrm{H} 2$ Boro is the source with the highest content of the micronutrient, regardless of the analyzed layer and doses, not being a source indicated for supplying B via soil, but it can be used for foliar application, as in this case it proved to be a readily available source like boric acid, but with easy application for being liquid. If it is necessary to apply it via soil, the dose needs to be adjusted in order to make it economically feasible, but Wang et al. (1999) demonstrated that B leaching leads to economic loss; on the other hand, it can be a factor of safety when excessive doses of the nutrient are applied.

The control treatment (without B application), regardless of the soil layer, resulted in very low values of leached $\mathrm{B}$, which did not differ, proving the effectiveness of the evaluations when the sources and doses of B were applied. This result corroborates those reported by Rosolem and Bíscaro (2007), who also observed that when B was added to the soil, at dose of $5 \mathrm{~kg} \mathrm{ha}^{-1}$ in the form of boric acid, the amounts of B present in the water percolated through the soil columns were ten times higher than those found in the control treatment. 
Besides the sources and doses, the attributes of the soil also influence B leaching. The results obtained demonstrate that clayey soils with higher values of $\mathrm{H}+\mathrm{Al}$ and $\mathrm{CEC}$ have lower $\mathrm{B}$ leaching, which can be explained by the presence of clay, because it is able to form aggregates that protect organic and mineral compounds from leaching (Rosolem and Bíscaro, 2007). On the other hand, soils with higher sand contents have lower CEC and a high infiltration rate, so they have a negative relationship with B content, which is lost in greater quantity by leaching (Rosolem and Bíscaro, 2007).

In soils of the Cerrado biome, the main source of B is the decomposition of organic matter, and soils with clayey and medium (silty) texture tend to have a better relationship with organic matter due to CEC present in its formation minerals, which makes it possible to retain the added $\mathrm{B}$ for longer periods of time. It is worth also mentioning that during the year, the Cerrado regions undergo a long period of drought, which reduces the speed of organic matter decomposition, reducing the availability of $\mathrm{B}$ in the soil solution. In this case, attention should be paid to the adequate supply of B to plants, as they may exhibit symptoms of deficiency of this micronutrient, causing significant losses in yield (Gonçalves and Benedetti, 2004).

Our results are similar to those found by Chaudary and Shukla (2004), who observed that soil samples with sandy texture, poor in organic matter, also had lower contents of B. In this context, Communar and Keren (2006) demonstrated that soils subject to high levels of rainfall tend to have B available in the leached soil solution because they do not have colloids that retain this micronutrient, which was observed in the present study in soils with higher sand contents.

The amount of water applied during the experiment and the soil used are considerably important factors for the results obtained, because this mobility of B in the soil has also been observed by Rosolem and Bíscaro (2007) and Oliveira Neto et al. (2009), being justified not only by the doses and sources applied, but also by the high rainfall that occurred in the soil with medium texture and low $\mathrm{pH}$, as observed in this experiment.

The amounts of fertilizers applied will depend on the nutritional needs of the species used, soil fertility, form of reaction of fertilizers with the soil, efficiency of fertilizers, economic factors and local water availability (Ryan et al., 2010). Both the source used and the dose and form of application of B fertilization should take into account the crop under study, because Dias et al. (2016), evaluating the application of $\mathrm{B}$ doses $\left(1,3,6,9\right.$ and $\left.12 \mathrm{~kg} \mathrm{ha}^{-1}\right)$ in three types of soil, observed no significant increase in the dry matter production of Brachiaria, regardless of the source. Nomura et al. (2011) state that fertilization applied directly in the soil and in the orifice of the thinned banana sucker is more efficient in supplying B when compared to foliar application. Therefore, applying $\mathrm{B}$ in the soil and on the leaves considerably increase the contents available in the soil at doses from 3 to $4 \mathrm{~g} \mathrm{plant}^{-1}$.

The results demonstrate the importance of studying the sources and doses of $\mathrm{B}$, because Bologna and Vitti (2006), evaluating the effect of sources and doses of B on the physical attributes of orange fruits, observed that the sources of B influenced their diameter, and the highest and lowest values were obtained with the sources of highest and lowest solubility, 
respectively, boric acid and colemanite.

Regardless of the dose applied, the ulexite source led to the lowest soluble B content in the profile of the analyzed soils and also in the leachate.

The more soluble sources, in this case boric acid and H2 Boro, regardless of the dose, showed relatively similar behaviors, with higher $\mathrm{B}$ contents in the leachate and in the profile of the Oxisol used.

Soils with clayey texture and higher values of $\mathrm{H}+\mathrm{Al}$ and $\mathrm{CEC}$ were able to retain higher $\mathrm{B}$ contents in the upper part of their profiles (layers from 0 to $10 \mathrm{~cm}$ and 11 to $20 \mathrm{~cm}$ ), but soils with sandy texture and higher values of sum of bases had greater B losses by leaching.

\section{Acknowledgments}

We thank the State University of Goiás for the PBIC scholarship granted to S.D.C. and financial support.

\section{References}

Alvares, C. A., Stape, J. L., Sentelhas, P. C., Gonçalves J. L. M., \& Sparovek G. (2013). Köppen's climate classification map for Brazil. Meteorologische Zeitschrift, 22(1), 711-728. https://doi.org/10.1127/0941-2948/2013/0507

American Psychological Association. (1972). Ethical standards of psychologists. Washington, DC: American Psychological Association.

Azevedo, R. A., Faquin, V., \& Fernandes LR. (2001). Adsorção de boro em solos de várzea do Sul de Minas Gerais. Pesquisa Agropecuária Brasileira, 36(1), 957-964. https://doi.org/10.1590/S0100-204X2001000700005

Bologna, I. R., \& Vitti, G. C., (2006). Produção e qualidade de frutos de laranjeira 'pêra' em função de Fontes e doses de boro. Revista Brasileira de Fruticultura, 28(1), 328-330. https://doi.org/10.1590/S0100-29452006000200040

Byers, D. E., Mikkelsen, R. L., \& Cox F. R. (2001). Greenhouse evaluation of four boron fertilizer material. Journal of Plant Nutrition, 24(1), 717-725. https://doi.org/10.1081/PLN-100103665

Chaudhary, D. R., \& Shukla, L. M., (2004). Boron adsorption and desorption in arid soils of India. Agrochimica, 48(1), 141-152. https://doi.org/10.1002/(SICI)1522-2624(199903)162:2<183:AID-JPLN183>3.0.CO;2-A

Communar, G., \& Keren, R. (2007) Effect of transient irrigation on boron transport in soils. Soil Science Society of America Journal, 71(2), 306-313. https://doi.org/10.2136/sssaj2005.0370

Dias, R. C., Texeira, P. C., Polidoro, J. C., Gonçalves, G. M., \& Zonta, E. (2016). Efeito de fontes e doses de boro na produção de matéria seca e acúmulo de nutrientes em plantas de braquiária. Rio de Janeiro: Embrapa Solos. 


\section{$\triangle 1$ Macrothink}

Journal of Agricultural Studies

ISSN 2166-0379

2021, Vol. 9, No. 2

Embrapa. (2018). Sistema Brasileiro de Classificação de Solos. 3 ed. Rio de Janeiro; Centro Nacional de Pesquisa de Solos.

Favaretto, N., Motta, A. C. V., Barck, C., Lustosa, S. B., \& Comin, J. J.(2007). Shoot and Root Response of Trifolium vesiculosum to Boron Fertilization in an Acidic Brazilian Soil. Brazilian Archives of Biology and Technology, 50(1), 597-604. https://doi.org/10.1590/S1516-89132007000400005

Fernandes, M. S. (2006). Nutrição Mineral de Plantas. Sociedade Brasileira de Ciência do Solo. Viçosa. 432 p.

Foloni, J. S. S., Garcia, R. A., Cardoso, C. L., Teixeira JP., \& Grassi Filho, H. (2010). Desenvolvimento de grãos e produção de fitomassa do Girassol em função de adubações boratadas. Bioscience Journal, 26(1), 273-280.

Goldberg, S., \& Glaubig, R. A. (1985). Boron adsorption on aluminum and iron oxide minerals. Soil Science Society of America Journal, 49(1), 1374-1379. https://doi.org/10.2136/sssaj1985.03615995004900060009x

Gonçalves, J. L. M., \& Benedetti V. (2004). Forest nutrition and fertilization. 2. ed. Piracicaba: Instituto de Pesquisa e Estudos Florestais.

Kassambara, A., \& Mundt, F., (2017). Factoextra: Extract and Visualize the Results of Multivariate Data Analyses. $\mathrm{R}$ package version 1.0.5.999. Available from: http://www.sthda.com/english/rpkgs/factoextra

Leite, R. F. C., Schuch, L. O. B., Amaral, A. S., \& Tavares, L. C. (2011). Rendimento e qualidade de sementes de arroz irrigado em função da adubação com boro. Revista Brasileira de Sementes, 33(1), 785-791. https://doi.org/10.1590/S0101-31222011000400021

Lima, J. C. P. S., Nascimento, C. W. A., Lima, J. G. C., \& Lira Junior, M. A. (2007). Níveis críticos e tóxicos de boro em solos de Pernambuco determinados em casa de vegetação. $\begin{array}{lllll}\text { Revista Brasileira de Ciência do } & \text { Solo, } & 31(1),\end{array}$ https://doi.org/10.1590/S0100-06832007000100008

Lordkaew, S., Konsaeng, S., Jongjaidee, J., Dell, B., Rerkasem, B., \& Janjod, S. (2013). Variation in responses to boron in rice. Plant and Soil, 363(1), 287-295. https://doi.org/10.1007/s11104-012-1323-3

Mendiburu, F., (2017) Agricolae: Statistical procedures for agricultural research. R package version 1. Available from: https://CRAN.R-project.org/package=agricolae.

Mortvedt, J. J. (1994). Needs for controlled-availability micronutrient fertilizers. Fertilizer Research, 38(1), 213-221. https://doi.org/10.1007/BF00749694

Murphy, L. S., \& Walsh, L. M. (1972). Fertilizer applications for correcting micronutrient deficiencies. In: Mortvedt, J. J, Giordano, P. M., \& Indsay WL, editors. Micronutrients in agriculture. Madison: Soil Science Society of America. p.347-387.

Nomura, E. S., Texeira, L. A. J., Boaretto, R. M., Garcia, V. A., Fuzitani, E. J., Junior 
Damatto, E. R., Saes, L. A., \& Junior Mattos, D. (2011). Aplicação de boro em bananeira. Revista Brasileira de Fruticultura, 33(1), 608-617. https://doi.org/10.1590/S0100-29452011000200034

Oliveira Neto, W., Muniz, A. S., Silva, G. A. M., Castro, C., \& Borkert, M. C. (2009). Boron extraction and vertical mobility in Paraná State Oxisol, Brazil. Revista Brasileira de Ciência do Solo, 33(1), 1259-1267. https://doi.org/10.1590/S0100-06832009000500019

R Core Team. (2018). R: A Language and Environment for Statistical Computing. Vienna, Austria: R Foundation for Statistical Computing. Available from: https://www.r-project.org/.

Rosolem CA, Bíscaro T. (2007). Adsorção e lixiviação de boro em Latossolo Vermelho-Amarelo. Pesquisa Agropecuária Brasileira, 42(1), 1473-1478. https://doi.org/10.1590/S0100-204X2007001000015

Ryan, G. M., Stape, J. L., Binkley, D., Fonseca. S., Loos, A. R., Takahashi, E. M., ... Silva G. C. (2010). Factors controlling Eucalyptus productivity: how water availability and stand structure alter production and carbon allocation. Forest Ecology and Management, 259(1), 1695-1703 https://doi.org/10.1016/j.foreco.2010.01.013

Saltali, K., Bilgili, A.V., Tarakcioglu, C., Durak, A. (2005). Boron adsorption in soils with different characteristics. Asian Journal of Chemistry, 17(1), 2487-2494.

Silva, F. C. (2009). Análise química de tecido vegetal. In: Silva FC, editor. Manual de Análises Químicas de Solo, Plantas e Fertilizantes. 2rd ed. Brasília: Embrapa Informação Tecnológica. p. 193-204.

Trautmann, R. R., Lana, M. C., Guimarães, V. F., Gonçalves, J. A. C., \& Steiner F. (2014). Potencial de água do solo e adubação com boro no crescimento e absorção do nutriente pela cultura da soja. Revista Brasileira Ciência Solo, 38(1), 240-251. https://doi.org/10.1590/S0100-06832014000100024

Wang, K., Yang, Y., Bell, R. W., Xue, J. M., Ye ZQ., \& Wei, Y. Z. (1999). Low risks of toxicity from boron fertilizer in oilseed rape-rice rotations in Southeast China. Nutri Cycl Agroecosyst, 54(1), 189-197. https://doi.org/10.1023/A:1009714132135

Wickham, H. (2016). Elegant Graphics for Data Analysis. 2nd ed. Berlim: Springer Verlag. Available from: http://www.springer.com/gp/book/9783319242750

\section{Copyright Disclaimer}

Copyright for this article is retained by the author(s), with first publication rights granted to the journal.

This is an open-access article distributed under the terms and conditions of the Creative Commons Attribution license (http://creativecommons.org/licenses/by/4.0/). 